\title{
Design and Performance Calculation using MATLAB for Multiple Effect Evaporator Desalination Process with Different Configurations
}

\author{
A. S. Nafey ${ }^{a}$, Mahmoud Abdelaal ${ }^{b}$, Amaal Mohey Elden ${ }^{\text {** }}$, and Rehab M. El-Maghraby ${ }^{c, d}$ \\ ${ }^{a}$ Mechanical Engineering Department, Faculty of Engineering, Suez University, Suez, Egypt \\ ${ }^{b}$ Electrical Engineering Department, Faculty of Engineering, Suez University, Suez, Egypt \\ ${ }^{c}$ Petroleum Refinery and Petrochemical Engineering Department, Faculty of Petroleum and Mining Engineering, Suez Unive rsity, Suez, Egypt \\ ${ }^{d}$ Oil and Green Chemistry Research Centre / Enhanced Oil Recovery Laboratory, Suez University, Suez, Egypt
}

\begin{abstract}
In this study modular MATLAB program is presented, where an equation oriented programming with MatLab 2020 is used to provide friendly user-interface of the developed program. This program can be used to perform reliable design, performance, and optimization calculations for multiple effect evaporator (MEE) desalination systems with different configurations under different operating conditions. In addition, by using this program modifications for existing desalination plants can be conducted. The developed program manipulates the considered configuration based on the graph theory with the number of units, streams and their types where the relationships between the streams and the units are identified. The program constructs a large matrix that is solved for temperatures, flow rates of the streams and the heat transfer area of the effects and heat exchangers. The accuracy and reliability of our program were verified using six different cases from the available data in the literature. These cases include forward, backward, mixed, and parallel feed MEE configurations with and without thermal-vapor compressor. Different computation modes were used for large number of plant configurations, this illustrates the capability of the developed program. Comparable and accurate results were obtained, the absolute relative errors for the studied cases ranged from $0.412 \%$ to $11.292 \%$. This indicates that the program has potential applicability to work with different configuration for Multiple Effect Evaporator (MEE) desalination plants.
\end{abstract}

Keywords: Multiple effect evaporator, Water desalination, MATLAB, Different configurations, Graph theory.

\section{INTRODUCTION}

Securing fresh water sources form an urgent matter for the life of human kind. The scarcity of fresh water needed for domestic uses in many parts around the world, in addition to the increasing population rate have driven the need for fresh water on our planet. Desalination process is one of the processes currently being used to provide fresh water of quality suitable for human uses. In the deslination process, dissolved salts from saline and brackish water is removed to yield fresh water. Desalination techniques include thermal and membrane techniques. Thermal desalination is based on evaporation and condensation such as multple effect evaporation (MEE) and multi-stage flash (MSF), while, the reverse omosis (RO) membrane technology is based on applying pressure on a semipermeable membrane. RO is the most widely applied technique followed by MSF and MEE [1]. However, the major challenge facing the desalination technology is minimizing energy consumption and increasing system efficiency. Integration of the desalination plants with power plants can save energy needed for thermal desalination [2]. Also, combining different techniques in one hybrid system can increase the total system efficiency. For instance, combining the advantages of RO and thermal desalination technologies in one hybrid system such as MSF-RO and MEE-RO increases the system performance ratio and minimizes the unit product cost [3]. Additionally, incorporating renewable energy, such as solar and wind energy sources besides fossil fuels, enhance the total system energy efficiency.

By comparing the different desalination methods, it was found that MEE has some unique advantages over both the MSF method and the RO method. In the MEE method, both corrosion and scaling of the equipment can be effectively controlled, which is not the case with the MSF method. The top brine temperature in the MEE method $\left(<70{ }^{\circ} \mathrm{C}\right)$ is much lower than that in the case of the MSF method ( from 90 to $110^{\circ} \mathrm{C}$ ). Moreover, in the MEE method, the feed seawater is simply pretreatment using less amount of chemicals, in the mean time, higher water quality can be obtained compared to than of the RO method [4]. It is clear that the MEE method is of high flexibility and has low operation temperature, this facilitates the integration of this method with industrial processes to recover waste heat [5].

Integrating MEE with other desalination systems can improve the total system performance by optimizing the design and the operating parameters, hence, the specific energy consumption is reduced. Generally, the desalination systems are displayed in terms of units and streams that are modeled by a system of equations that need a programming technique to solve. This technique is called flowsheeting programming [6]. This technique has two approaches; the sequential-oriented and the equation-oriented. For the first approach, each unit has its program that can be solved individually and the output stream data for each unit is used as an input for the next unit. While for the equation-oriented approach, the plant unit model equations, 
connecting equations, and specifications are expressed in large system of linear and non-linear equations that can be solved iteratively and simultaneously for all the unknown variables [7].

According to the available data in the literature, there are many computer programs that were developed to simulate, design and optimize the desalination processes. This development was conducted through out three generations. The first generation is concerned with special purpose programs to analyze problems of fixed unit/ process configurations. These programs have simple structures. Large number of the available programs in the literature adopt this approach as the case in [8],[9] and [10]. However, the disadvantages of these programs are their rigidity to simulate only one process and any changes made to it may need substantial reprogramming.

To overcome such limitations, the second generation was concerned with either general purpose programs or modular programs (flow sheeting approach). In the second generation programs, the formulation of the mathematical model is derived using set of equations representing the unit processes. A thermodynamic power cycle calculations was conducted by [11] using a flexible computer program. The components of the desaliation plant - displayed in a library - were connected under DOS. In addition, FORTRAN program was used in some researches as the case with [12] to solve multi-stage flash desalination plants under steady-state conditions. The equationoriented approach was used to construct a sensitivity matrix by decomposing the system. However, an expert user is required to input the required data [13].

However, a third generation of computer programming started in the literature where the visual modular program approach is adopted so as to allow the user to build the process and enter the date easily. An example of these visualized programs is the one developed by [14] for power station plants where different configurations can be considered based on a library of thermal units. An object-oriented program was developed by Uche et al. [15] where Java language is used to build water and energy systems blocks.

Mabrouk et. al. [16] developed a visual computer package (VDS) program with friendly-user interface to design and simulate different conventional desalination processes. This enabled the operator to modify an existing plant or to develop a new design of different configuration. However, a "Variable Type by Variable Type (VTBVT)" decomposition technique was used to build the large matrix, this technique limited the flexibility and generality of the program. In addition, other limitations are caused by the nested recycle streams and the matrix size [13].

Recently, MatLab showed high capability to perform different mathematical computations including processes under steady and dynamic states. Abdelwahab [13] used MATLAB/Simulink to develope a modular program for different configurations of solar desalination systems. Simulink has the cababilty of building blocks on a graphical user interface. The program allows the users to easily change to the plant configurations variables and operating conditions.

Several models, in the literature, have been devoted to analyze different desalination plants with different configurations. ElDessouky et al. [17] developed a MEE model that accounts for the leakage of steam and non-condensable gases. El-Dessouky and Ettouney [18] developed different models for different MEE and MEE-TVC (thermal-vapor compressor) desalination systems. Darwish et al. [19] developed a MEE model to properly locate the TVC connected to the MEE system assuming constant thermodynamics properties and independent on temperature and salinity. Both parallel and forward feed configurations are investigated using this model. Maha BenHamad et al. [20] modeled and simulated the MEE-TVC desalination system under steady-state conditions. Results obtained from a commercial unit installed in the Tunisian Chemical Group (GCT) factory was used to validate their model. Kaya and Sarac [8] stated a model for each configuration of six-effect evaporator systems. Nafey [7] developed the variable-type by the variable type (VTBVT) technique where the linearized model equations can be grouped based on the variable type. The model matrices are programmed with FORTRAN language which processed under the DOS operating system. This system has some limitations such as the need for an expert user to enter the data and it is relatively time-consuming.

It is clear from the data available in the literature that there are a need for a flexible computer program for the desalination techniques. In this study, a flexible modular computer flowsheeting program is constructed for the design, performance evaluation and optimization of the different MEE configurations based on graph theory [21]. The capability of the MATLAB platform in the development process of the present program is implemented in this work. The accuracy and reliability of our program was verified using 6 case studies from the available data in the literature.

\section{Program Development}

The developed program, presented in this work, can deal with different configurations of MEE under different operating conditions. Depending on the material and energy balance, each unit is represented by a set of equations which express the relationship between the variables. MATLAB functions are developed for each unit according to its mathematical model equations and the number of variables. Equation-oriented approach is used to manipulate the generated mathematical models. Temperature and flow rate of the considered process streams are among the output of the program. Also, heat transfer areas and performance results are considered among the variables. The developed program is divided into the following sections:

\section{II.I Configuration Description}

The different configurations of MEE systems can be described by the means of graph theory. The graph is a set of points in space that are referred to as vertices. The vertices are connected 
by line segments referred to as edges [21]. In the developed program, the units of the configuration are described by the vertices while the streams are the egdes. Each egde (stream) connects two vertices (the unit). One vertex is the source node while the other is the target node. By defining the source unit, the target unit, their types, and the type of each stream, the system configuration will be able to identify the input and output of each unit. Then, the system configuration is translated into an incidence matrix that can be solved for the system variables. As shown in Fig. 1, as an example, the source node is defined by the array [A E B B B C D C E], and the target node by the array [B B C G H I C E F] where the array elements represent the unit number. While the stream type is defined by the array [V W V W C C W W W], and the unit type by the array [F E C F S R R R P] where V, W, C represent vapor, salt water and condensate respectively for the stream type, and F, E, C, S, R, P represent feed, effect, condenser, splitter, rejected and product respectively for the unit type.

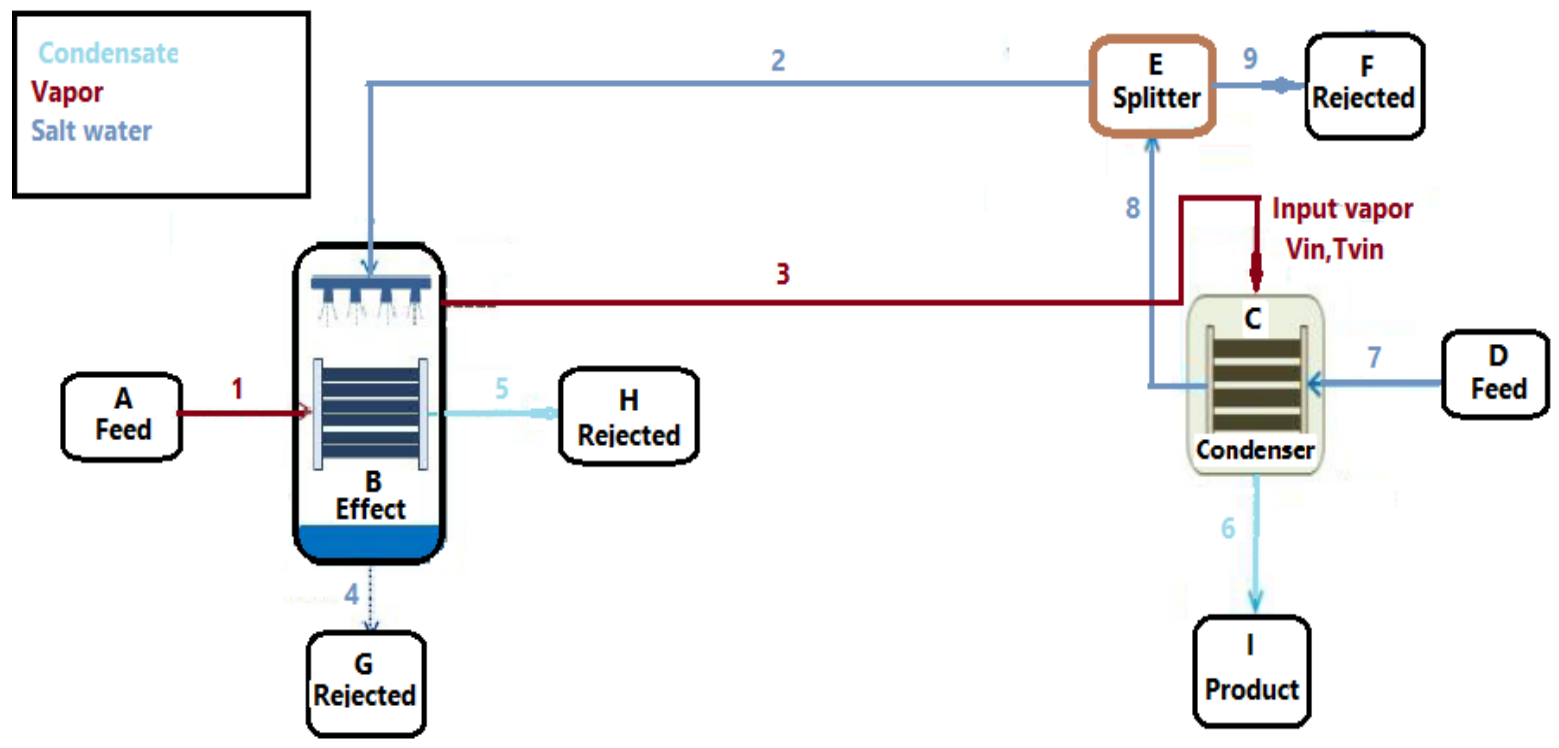

(a)

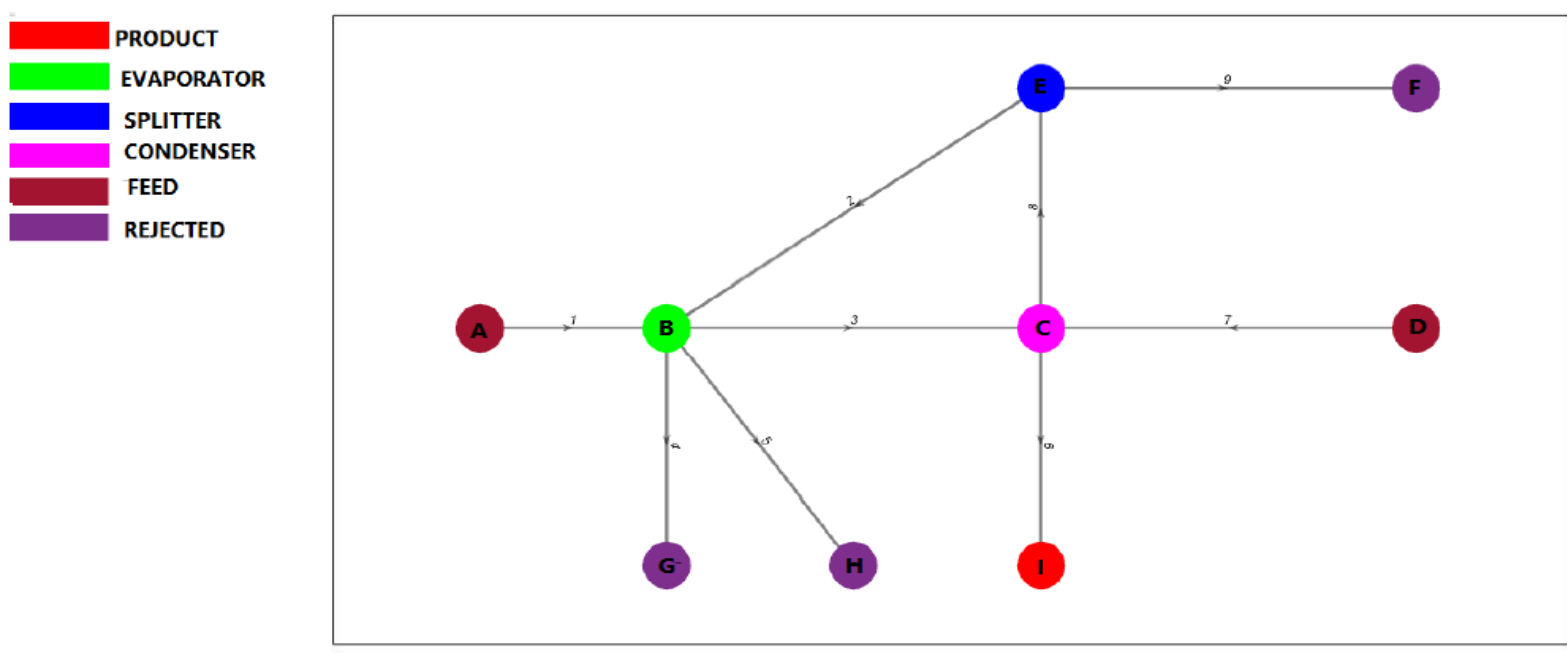

(b)

Fig.1: (a) Illustrative example of describing system configuration using graph theory, (b) MATLAB output of describing system configuration using graph theory.

\section{II.II Type of Calculations}

The developed program is divided into three modes; the first mode is the design calculation, the second mode is the performance calculation, and the third mode is the optimization calculation. The user/engineer selects the mode according to the calculation type that is needed.

\section{II.III Defining the Input Data}

The program asks the user to enter the given input data for the case, the data of steam temperature $\left(T_{s}\right)$, seawater feed 
temperature $\left(T_{f}\right)$, cooling water temperature $\left(T_{c w}\right)$, last effect temperature $\left(T_{n}\right)$, feed salinity $\left(X_{f}\right)$, rejected brine salinity $\left(X_{b}\right)$, number of units $(n)$ and the total product flow rate $\left(M_{d}\right)$, the temperature from first effect $\left(T_{1}\right)$

\section{II.IV Constructing and Solving the System Matrix}

According to the data entered/assigned in the previous sections, the program performs the required computation for the constructed matrix of the considered process. This iterative computation for the unknown variables is stopped at specified tolerance. The output results are obtained and represented in a graph and tabulated forms at last section of the program.

\section{Application and Verification of the Developed Program}

To illustrate the capability and the accuracy of the developed program, six different cases will be considered;

\section{III.I Case 1: Six-Evaporator Forward Feed Plant}

In this case, six-evaporator forward feed plant is considered using the developed program design and performance computation modes. For forward feed plants, the water feed flows in the same directions as the vapor as shown in Fig. 2. a. The input data for the case is given in Table 1 [18] and the comparison is shown in Table 2 .

Table 1: Input data for case 1 [18]

\begin{tabular}{|l|l|}
\hline Total product flowrate & $1 \mathrm{~kg} / \mathrm{s}$ \\
Motive steam temperature & $100{ }^{\circ} \mathrm{C}$ \\
Feed seawater temperature & $35^{\circ} \mathrm{C}$ \\
Vapor temperature in the last effect & $40{ }^{\circ} \mathrm{C}$ \\
Salt concentration in feed seawater & $42000 \mathrm{ppm}$ \\
Salt concentration in rejected brine & $700000 \mathrm{ppm}$ \\
The overall heat transfer coefficient in the first effect & $2.4 \mathrm{KW} / \mathrm{m}^{2}{ }^{\circ} \mathrm{C}$ \\
Condenser overall heat transfer coefficient & $1.75 \mathrm{KW} / \mathrm{m}^{2}{ }^{\circ} \mathrm{C}$ \\
The specific heat capacity & $4.2 \mathrm{KJ} / \mathrm{Kg}^{\circ} \mathrm{C}$ \\
\hline
\end{tabular}

Table 2: Comparison of the output results obtained for brine and vapour temperature, ${ }^{\circ} \mathrm{C}$, and flow rate, $\mathrm{kg} / \mathrm{s}$ using our program in case 1

\begin{tabular}{|c|c|c|c|c|c|c|c|c|c|c|c|c|}
\hline \multirow{2}{*}{$\begin{array}{c}\text { Effect } \\
\text { Number }\end{array}$} & \multicolumn{3}{|c|}{ Brine temperature $\left({ }^{\circ} \mathrm{C}\right)$} & \multicolumn{3}{|c|}{ Vapor temperature $\left({ }^{\circ} \mathrm{C}\right)$} & \multicolumn{3}{|c|}{ Brine flow rate $(\mathrm{kg} / \mathrm{s})$} & \multicolumn{3}{|c|}{ Vapor flow rate $(\mathrm{kg} / \mathrm{s})$} \\
\hline & $\begin{array}{l}\text { Design } \\
\text { Mode }\end{array}$ & $\begin{array}{c}\text { Performance } \\
\text { Mode }\end{array}$ & $\begin{array}{c}\mathrm{ARE} \\
\%\end{array}$ & $\begin{array}{l}\text { Design } \\
\text { Mode }\end{array}$ & $\begin{array}{c}\text { Performance } \\
\text { Mode }\end{array}$ & $\begin{array}{c}\text { ARE } \\
\%\end{array}$ & $\begin{array}{l}\text { Design } \\
\text { Mode }\end{array}$ & $\begin{array}{c}\text { Performance } \\
\text { Mode }\end{array}$ & $\begin{array}{c}\mathrm{ARE} \\
\%\end{array}$ & $\begin{array}{l}\text { Design } \\
\text { Mode }\end{array}$ & $\begin{array}{c}\text { Performance } \\
\text { Mode }\end{array}$ & $\begin{array}{c}\mathrm{ARE} \\
\%\end{array}$ \\
\hline 1 & 92.507 & 92.499 & 0.0086 & 91.870 & 91.860 & 0.0109 & 2.329 & 2.329 & 0 & 0.171 & 0.171 & 0 \\
\hline 2 & 82.982 & 82.983 & 0.0012 & 82.327 & 82.324 & 0.0036 & 2.159 & 2.160 & 0.0463 & 0.169 & 0.169 & 0 \\
\hline 3 & 73.041 & 73.064 & 0.0315 & 72.365 & 72.381 & 0.0221 & 1.992 & 1.992 & 0 & 0.168 & 0.168 & 0 \\
\hline 4 & 62.710 & 62.764 & 0.0861 & 62.008 & 62.051 & 0.0693 & 1.826 & 1.826 & 0 & 0.166 & 0.166 & 0 \\
\hline 5 & 51.946 & 52.035 & 0.1713 & 51.211 & 51.286 & 0.1465 & 1.662 & 1.662 & 0 & 0.164 & 0.164 & 0 \\
\hline 6 & 40.727 & 40.854 & 0.3118 & 39.950 & 40.059 & 0.2728 & 1.500 & 1.499 & 0.0667 & 0.162 & 0.163 & 0.6173 \\
\hline
\end{tabular}

In this case, the calculations are based on assuming that the evaporators have the same area. Assuming that the values in subsequent effects are calculated from $U_{i+1}=0.95 U_{i}$ [18]. The latent heat and boiling point elevation temperature are calculated using equations shown in Appendix. It was found that the system performance ratio, specific area, specific condenser area, specific cooling water and the inlet vapor flow rate to the first effect are $5.099,168.780 \mathrm{~m} 2 / \mathrm{kg} / \mathrm{s}, 32.751$ $\mathrm{m}^{2} / \mathrm{kg} / \mathrm{s}, 6.7826$ and $0.1961 \mathrm{~kg} / \mathrm{s}$ respectively.

\section{III.II Case 2: Six-Evaporator Backward Feed Plant}

For Backward feed plants, the water feed flows in the opposite direction of the vapor as shown in Fig.2.b. Six-evaporator backward feed plant with condenser is solved using the developed design and performance computation modes yielding comparable results. The input data for the case is given in Table 1 [18]. The comparison results are shown in Table 3. The system performance ratio, specific area, specific condenser area, specific cooling water and the inlet vapor flow rate to the first effect are $5.655,166.700 \mathrm{~m}^{2} / \mathrm{kg} / \mathrm{s}, 29.138 \mathrm{~m}^{2} / \mathrm{kg} / \mathrm{s}, 5.749$ and $0.1768 \mathrm{~kg} / \mathrm{s}$ respectively. 
International Journal of Engineering Research and Technology. ISSN 0974-3154, Volume 13, Number 10 (2020), pp. 3029-3042

(C) International Research Publication House. https://dx.doi.org/10.37624/IJERT/13.10.2020.3029-3042

Table 3: Comparison of the output results obtained for brine and vapour temperature, ${ }^{\circ} \mathrm{C}$, and flow rate, $\mathrm{kg} / \mathrm{s}$ using our program in case 2

\begin{tabular}{|c|c|c|c|c|c|c|c|c|c|c|c|c|}
\hline \multirow{2}{*}{$\begin{array}{c}\text { Effect } \\
\text { Number }\end{array}$} & \multicolumn{3}{|c|}{ Brine temperature $\left({ }^{\circ} \mathrm{C}\right)$} & \multicolumn{3}{|c|}{ Vapor temperature $\left({ }^{\circ} \mathrm{C}\right)$} & \multicolumn{3}{|c|}{ Brine flow rate $(\mathrm{kg} / \mathrm{s})$} & \multicolumn{3}{|c|}{ Vapor flow rate $(\mathrm{kg} / \mathrm{s})$} \\
\hline & $\begin{array}{l}\text { Design } \\
\text { Mode }\end{array}$ & $\begin{array}{c}\text { Performance } \\
\text { Mode }\end{array}$ & $\begin{array}{c}\text { ARE } \\
\%\end{array}$ & $\begin{array}{l}\text { Design } \\
\text { Mode }\end{array}$ & $\begin{array}{c}\text { Performance } \\
\text { Mode }\end{array}$ & $\begin{array}{c}\mathrm{ARE} \\
\%\end{array}$ & $\begin{array}{l}\text { Design } \\
\text { Mode }\end{array}$ & \begin{tabular}{|c} 
Performance \\
Mode
\end{tabular} & $\begin{array}{c}\text { ARE } \\
\%\end{array}$ & $\begin{array}{l}\text { Design } \\
\text { Mode }\end{array}$ & $\begin{array}{c}\text { Performance } \\
\text { Mode }\end{array}$ & $\begin{array}{c}\mathrm{ARE} \\
\%\end{array}$ \\
\hline 1 & 91.717 & 91.719 & 0.0022 & 90.752 & 90.748 & 0.0044 & 1.500 & 1.498 & 0.1333 & 0.175 & 0.174 & 0.5714 \\
\hline 2 & 81.960 & 81.991 & 0.0378 & 81.122 & 81.138 & 0.0197 & 1.675 & 1.673 & 0.1194 & 0.173 & 0.173 & 0 \\
\hline 3 & 71.793 & 71.873 & 0.1114 & 71.068 & 71.126 & 0.0816 & 1.848 & 1.846 & 0.1082 & 0.171 & 0.171 & 0 \\
\hline 4 & 61.240 & 61.386 & 0.2384 & 60.613 & 60.732 & 0.1963 & 2.019 & 2.017 & 0.0991 & 0.169 & 0.170 & 0.5917 \\
\hline 5 & 50.256 & 50.482 & 0.4497 & 49.714 & 49.908 & 0.3902 & 2.189 & 2.187 & 0.0914 & 0.167 & 0.168 & 0.5988 \\
\hline 6 & 40.821 & 41.132 & 0.7619 & 40.347 & 40.629 & 0.6989 & 2.356 & 2.355 & 0.0424 & 0.144 & 0.145 & 0.6944 \\
\hline
\end{tabular}

\section{III.III Case 3: Six-Evaporator Mixed Feed Plant}

In the mixed feed sequence Fig. 3 , the feed is given to $5^{\text {th }}$ effect and brine out from $5^{\text {th }}$ goes into $6^{\text {th }}$ and from $6^{\text {th }}$ to $4^{\text {th }}$ and from $4^{\text {th }}$ to $3^{\text {rd }}$ and so on up to the first effect. Six-evaporator mixed feed plant is solved using the developed program mode yielding comparable results. The input data for the case is given in Table 1 [18] and the comparison is shown in Table 4.
The system performance ratio, total specific area, specific condenser area, specific cooling water and the the inlet vapor flow rate to the first effect are $5.535,167.260 \mathrm{~m}^{2} / \mathrm{kg} / \mathrm{s}, 29.848$ $\mathrm{m}^{2} / \mathrm{kg} / \mathrm{s}, 5.956$ and $0.1807 \mathrm{~kg} / \mathrm{s}$ respectively.

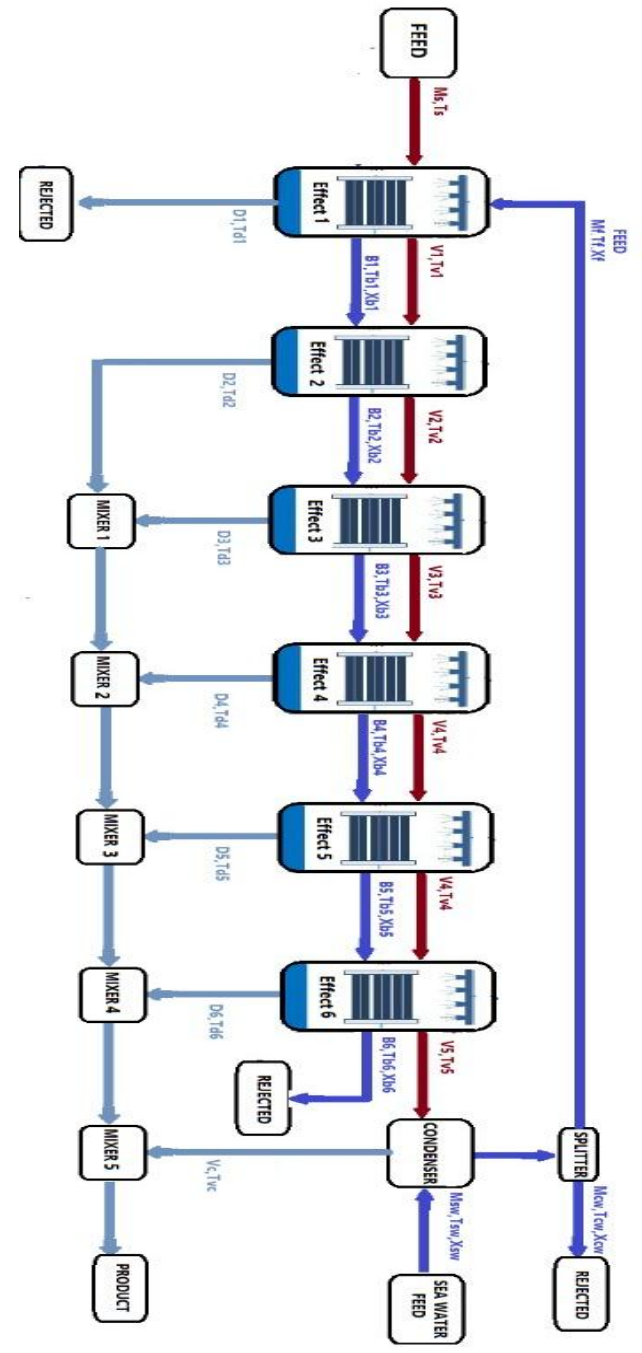

(a)

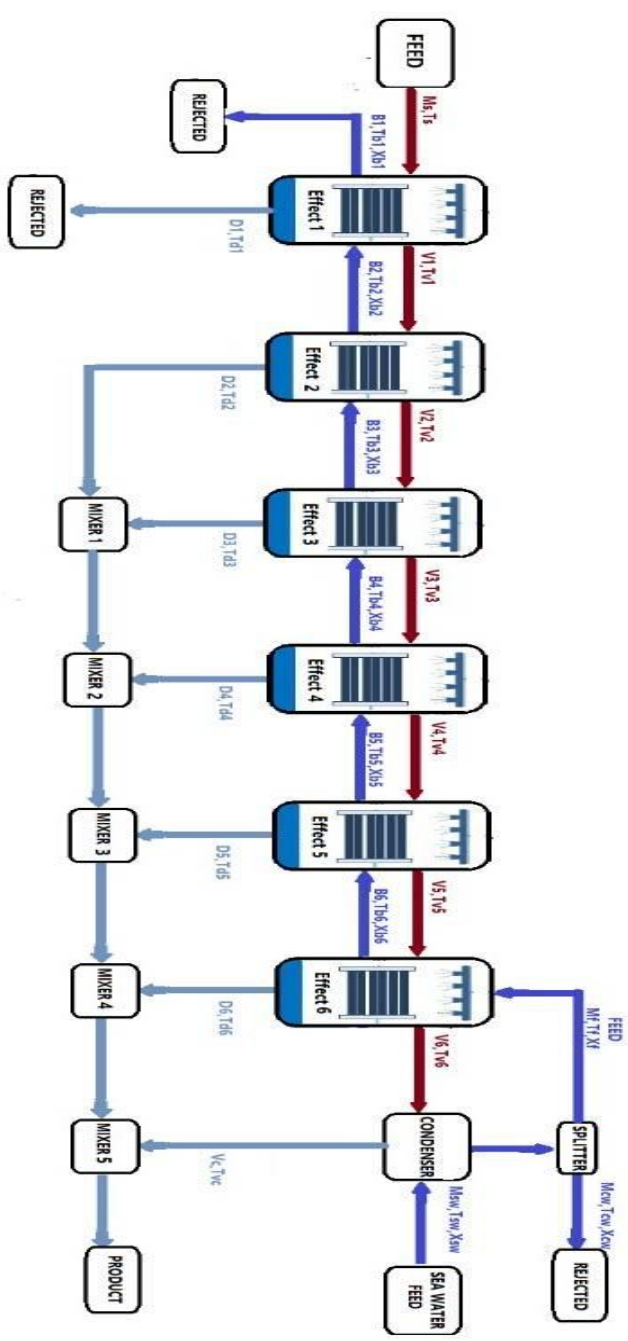

(b)

Fig.2: (a) Forward feed multiple effect evaporation, (b) Backward feed multiple effect evaporation. 
International Journal of Engineering Research and Technology. ISSN 0974-3154, Volume 13, Number 10 (2020), pp. 3029-3042

(C) International Research Publication House. https://dx.doi.org/10.37624/IJERT/13.10.2020.3029-3042

Table 4: Comparison of the output results obtained for brine and vapour temperature, ${ }^{\circ} \mathrm{C}$, and flow rate, $\mathrm{kg} / \mathrm{s}$ using our program in case 3

\begin{tabular}{|c|c|c|c|c|c|c|c|c|c|c|c|c|}
\hline \multirow{2}{*}{$\begin{array}{c}\text { Effect } \\
\text { Number }\end{array}$} & \multicolumn{2}{|c|}{ Brine temperature $\left({ }^{\circ} \mathbf{C}\right)$} & \multicolumn{2}{|c|}{ Vapor temperature $\left({ }^{\circ} \mathbf{C}\right)$} & \multicolumn{2}{c|}{ Brine flow rate (kg/s) } & \multicolumn{2}{c|}{ Vapor flow rate $(\mathrm{kg} / \mathbf{s})$} \\
\cline { 2 - 13 } & Mode & $\begin{array}{c}\text { Performance } \\
\text { Mode }\end{array}$ & $\begin{array}{c}\text { ARE } \\
\%\end{array}$ & $\begin{array}{c}\text { Design } \\
\text { Mode }\end{array}$ & $\begin{array}{c}\text { Performance } \\
\text { Mode }\end{array}$ & $\begin{array}{c}\text { ARE } \\
\%\end{array}$ & $\begin{array}{c}\text { Design } \\
\text { Mode }\end{array}$ & $\begin{array}{c}\text { Performance } \\
\text { Mode }\end{array}$ & $\begin{array}{c}\text { ARE } \\
\%\end{array}$ & $\begin{array}{c}\text { Design } \\
\text { Mode }\end{array}$ & $\begin{array}{c}\text { Performance } \\
\text { Mode }\end{array}$ & $\begin{array}{c}\text { ARE } \\
\%\end{array}$ \\
\hline $\mathbf{1}$ & 91.551 & 91.554 & 0.0033 & 90.586 & 90.583 & 0.0033 & 1.500 & 1.498 & 0.1333 & 0.179 & 0.178 & 0.5587 \\
\hline $\mathbf{2}$ & 81.617 & 81.648 & 0.0380 & 80.782 & 80.799 & 0.0210 & 1.679 & 1.677 & 0.1191 & 0.177 & 0.177 & 0 \\
\hline $\mathbf{3}$ & 71.264 & 71.343 & 0.1109 & 70.544 & 70.601 & 0.0808 & 1.856 & 1.853 & 0.1616 & 0.175 & 0.175 & 0 \\
\hline $\mathbf{4}$ & 60.517 & 60.659 & 0.2346 & 59.896 & 60.011 & 0.1920 & 2.030 & 2.029 & 0.0493 & 0.173 & 0.174 & 0.5780 \\
\hline $\mathbf{5}$ & 51.299 & 51.509 & 0.4094 & 50.794 & 50.980 & 0.3662 & 2.351 & 2.350 & 0.0425 & 0.149 & 0.150 & 0.6711 \\
\hline $\mathbf{6}$ & 40.957 & 40.241 & 1.7482 & 40.447 & 40.704 & 0.6354 & 2.203 & 2.202 & 0.0454 & 0.148 & 0.148 & 0 \\
\hline
\end{tabular}

III.IV Case 4: Four-Evaporator Parallel Feed Plant (Darwish and Hasan Case) [19]

For the input data given in Table 5 the output results of the developed program are compared with Darwish and Hasan [19]. The comparison yield acceptable results as shown in Table 6 and 7 for four-evaporator parallel feed plant with the condenser, Figure 4. In this case the design calculation depends on the fact that evaporators have different area. Assuming that the overall heat transfer coefficient for all evaporators and condenser respectively equal $3 \mathrm{KW} / \mathrm{m}^{2}{ }^{\circ} \mathrm{C}$, the boiling point elevation temperature is $0.7{ }^{\circ} \mathrm{C}$ and constant latent heat is 2383 $\mathrm{KJ} / \mathrm{Kg}$ and specific heat capacity is $3.9 \mathrm{KJ} / \mathrm{Kg}{ }^{\circ} \mathrm{C}$ [19]. The heat transfer area of the effects are given as 1563.9, 1353.3, $1219.3,1146 \mathrm{~m}^{2}$ respectively.

Table 5. Input data for case 4 [19]

\begin{tabular}{|l|l|}
\hline Total product flowrate & $52.616 \mathrm{~kg} / \mathrm{s}$ \\
Motive steam temperature & $73.33^{\circ} \mathrm{C}$ \\
Feed seawater temperature & $32.3^{\circ} \mathrm{C}$ \\
Vapor temperature in the last effect & $36{ }^{\circ} \mathrm{C}$ \\
Salt concentration in feed seawater & $46000 \mathrm{ppm}$ \\
Salt concentration in rejected brine & $69000 \mathrm{ppm}$ \\
\hline
\end{tabular}

Table 6: Comparison of the output results obtained for effect temperature, ${ }^{\circ} \mathrm{C}$, brine , vapor, and feed flow rate, $\mathrm{kg} / \mathrm{s}$ using our program in case 4

\begin{tabular}{|c|c|c|c|c|c|c|c|c|}
\hline \multirow{2}{*}{$\begin{array}{c}\text { Effect } \\
\text { Number }\end{array}$} & \multicolumn{2}{|c|}{ Temperature } & \multicolumn{2}{c|}{ Brine Flow Rate } & \multicolumn{2}{c|}{ Vapor Flow Rate } & \multicolumn{2}{c|}{ Feed } \\
\cline { 2 - 9 } & $\begin{array}{c}\text { Developed } \\
\text { program }\end{array}$ & $\begin{array}{c}\text { Darwish } \\
\text { and Hasan } \\
{[\mathbf{1 9 ]}}\end{array}$ & $\begin{array}{c}\text { Developed } \\
\text { program }\end{array}$ & $\begin{array}{c}\text { Darwish } \\
\text { and Hasan } \\
{[\mathbf{1 9}]}\end{array}$ & $\begin{array}{c}\text { Developed } \\
\text { pogram }\end{array}$ & $\begin{array}{c}\text { Darwish } \\
\text { and Hasan } \\
{[\mathbf{1 9 ]}}\end{array}$ & $\begin{array}{c}\text { Developed } \\
\text { program }\end{array}$ & $\begin{array}{c}\text { Darwish } \\
\text { and Hasan } \\
{[19]}\end{array}$ \\
\hline $\mathbf{1}$ & 64.000 & 64.000 & 29.347 & 27.306 & 14.699 & 13.653 & 44.096 & 40.959 \\
\hline $\mathbf{2}$ & 54.667 & 54.700 & 55.886 & 52.661 & 13.244 & 12.678 & 39.733 & 38.033 \\
\hline $\mathbf{3}$ & 45.333 & 45.300 & 80.781 & 78.004 & 12.448 & 12.671 & 37.343 & 36.013 \\
\hline $\mathbf{4}$ & 36.000 & 36.000 & 105.230 & 105.230 & 12.226 & 13.615 & 36.677 & 40.845 \\
\hline
\end{tabular}




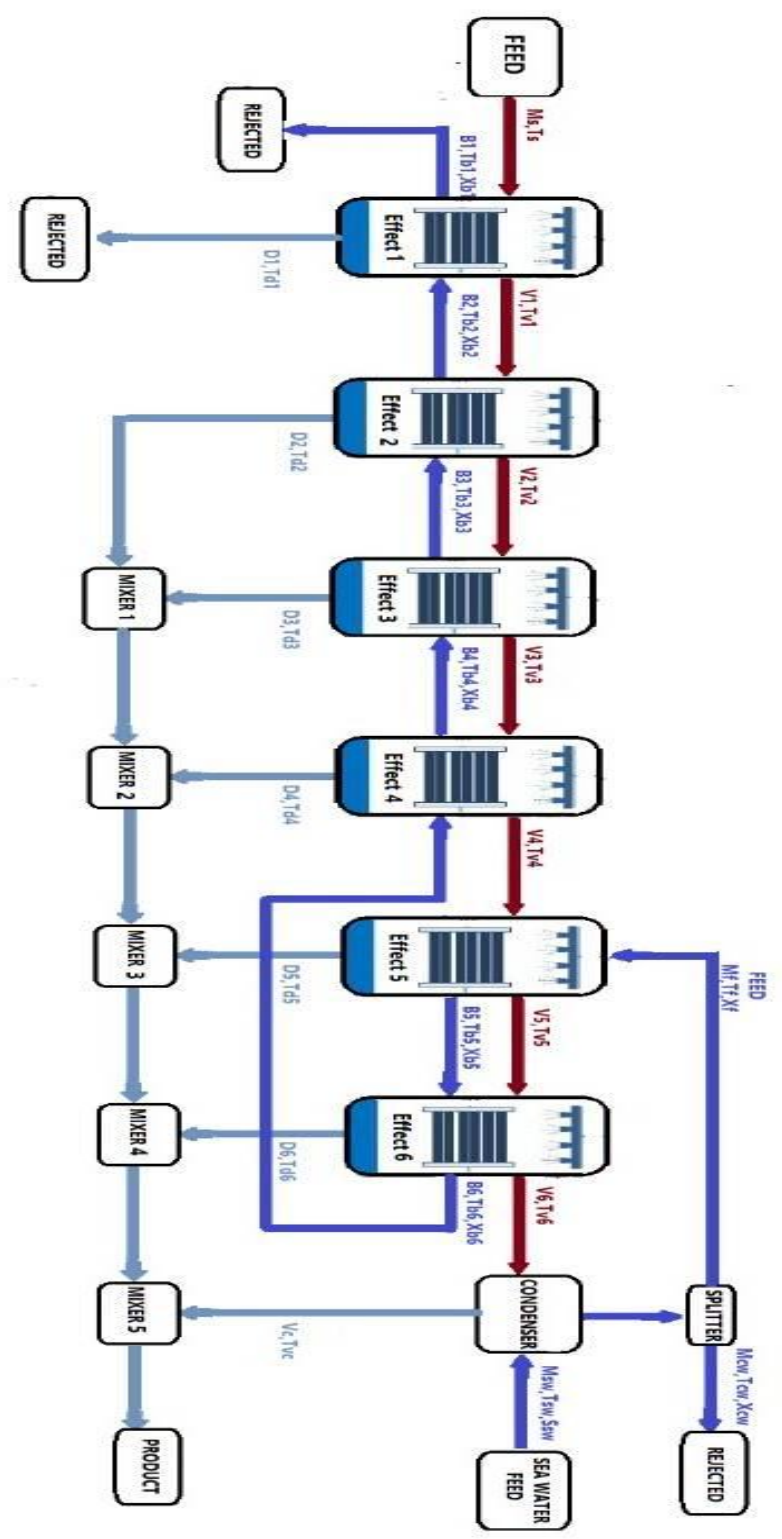

Fig. 3: Mixed feed multiple effect evaporation.

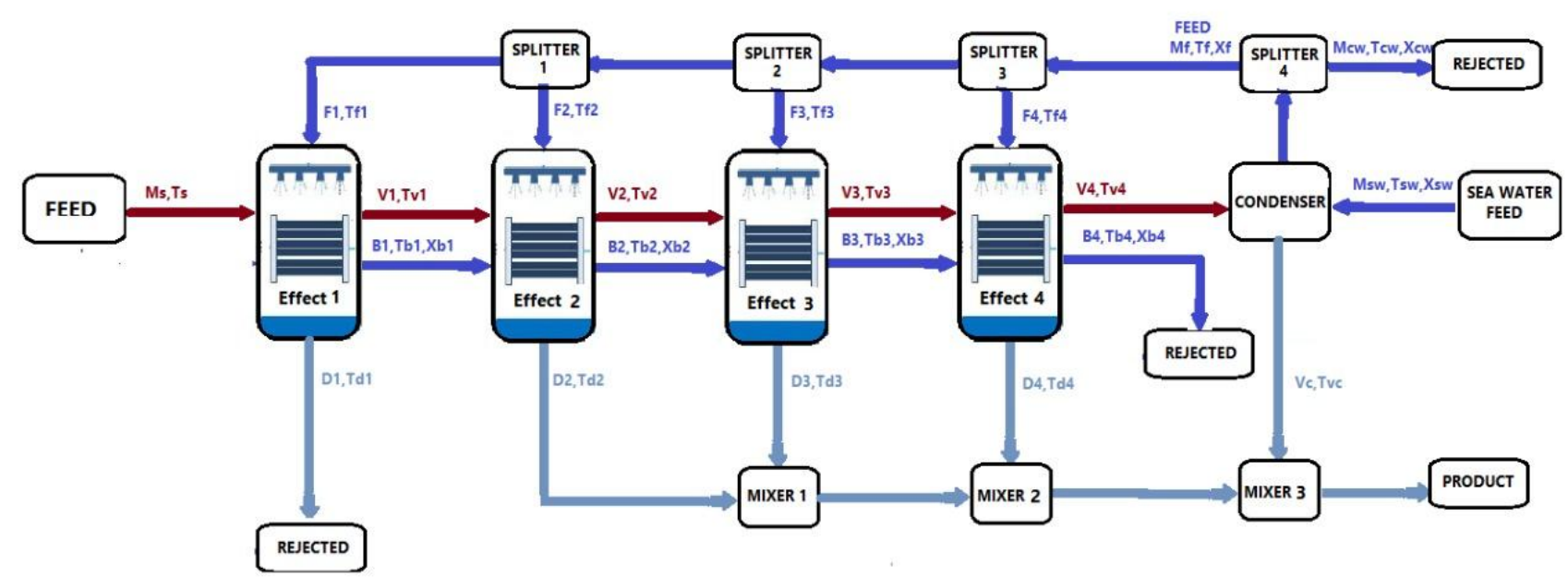

Fig. 4: Four-evaporator parallel feed plant. 
International Journal of Engineering Research and Technology. ISSN 0974-3154, Volume 13, Number 10 (2020), pp. 3029-3042

(C) International Research Publication House. https://dx.doi.org/10.37624/IJERT/13.10.2020.3029-3042

Table 7: Comparison of the output results obtained for between our program and data in [19] in case 4

\begin{tabular}{|l|c|c|}
\hline \multicolumn{1}{|c|}{ Variables } & Developed Program & Darwish and Hasan [19] \\
\hline Motive steam temperature $M_{S}(\mathrm{~kg} / \mathrm{s})$ & 16.986 & 15.778 \\
\hline Performance ratio $P R$ & 3.098 & 3.335 \\
\hline Total Specific heat transfer Area $S A\left(\mathrm{~m}^{2} /(\mathrm{kg} / \mathrm{s})\right)$ & 141.71 & - \\
\hline The specific heat transfer condenser area $S A_{c}\left(\mathrm{~m}^{2} /(\mathrm{kg} / \mathrm{s})\right)$ & 41.372 & - \\
\hline The specific flow rate of cooling water $S M_{c w}$ & 30.458 & - \\
\hline
\end{tabular}

III.V Case 5 : Four-Evaporator MEE-FF/TVC (Khalid et al. Case) [22]

For the input data given in Table 8 , the output results of the developed program are compared with Khalid et al. results and Eldesoukey and Ettouney results [18] yielding reasonable results as shown in Table 9 for four-evaporator forward feed plant with thermal vapor compressor, Fig. 5. In this case, the calculation depends on the same assumption of case 1 . The heat transfer area in each effect is equal $78.5378 \mathrm{~m}^{2}$.

Table 8: Input data for case 5 [22]

\begin{tabular}{|l|l|}
\hline Total product flowrate & $1 \mathrm{~kg} / \mathrm{s}$ \\
Motive steam temperature & $60^{\circ} \mathrm{C}$ \\
Feed seawater temperature & $35^{\circ} \mathrm{C}$ \\
Vapor temperature in the last effect & $40^{\circ} \mathrm{C}$ \\
Salt concentration in feed seawater & $42000 \mathrm{ppm}$ \\
Salt concentration in rejected brine & $70000 \mathrm{ppm}$ \\
Cooling seawater temperature & $25^{\circ} \mathrm{C}$ \\
Motive steam pressure & $250 \mathrm{kpa}$ \\
Cooling water & $9.316 \mathrm{~kg} / \mathrm{s}$ \\
\hline
\end{tabular}

Fig. 5: Forward feed multi-effect evaporation system with TVC.

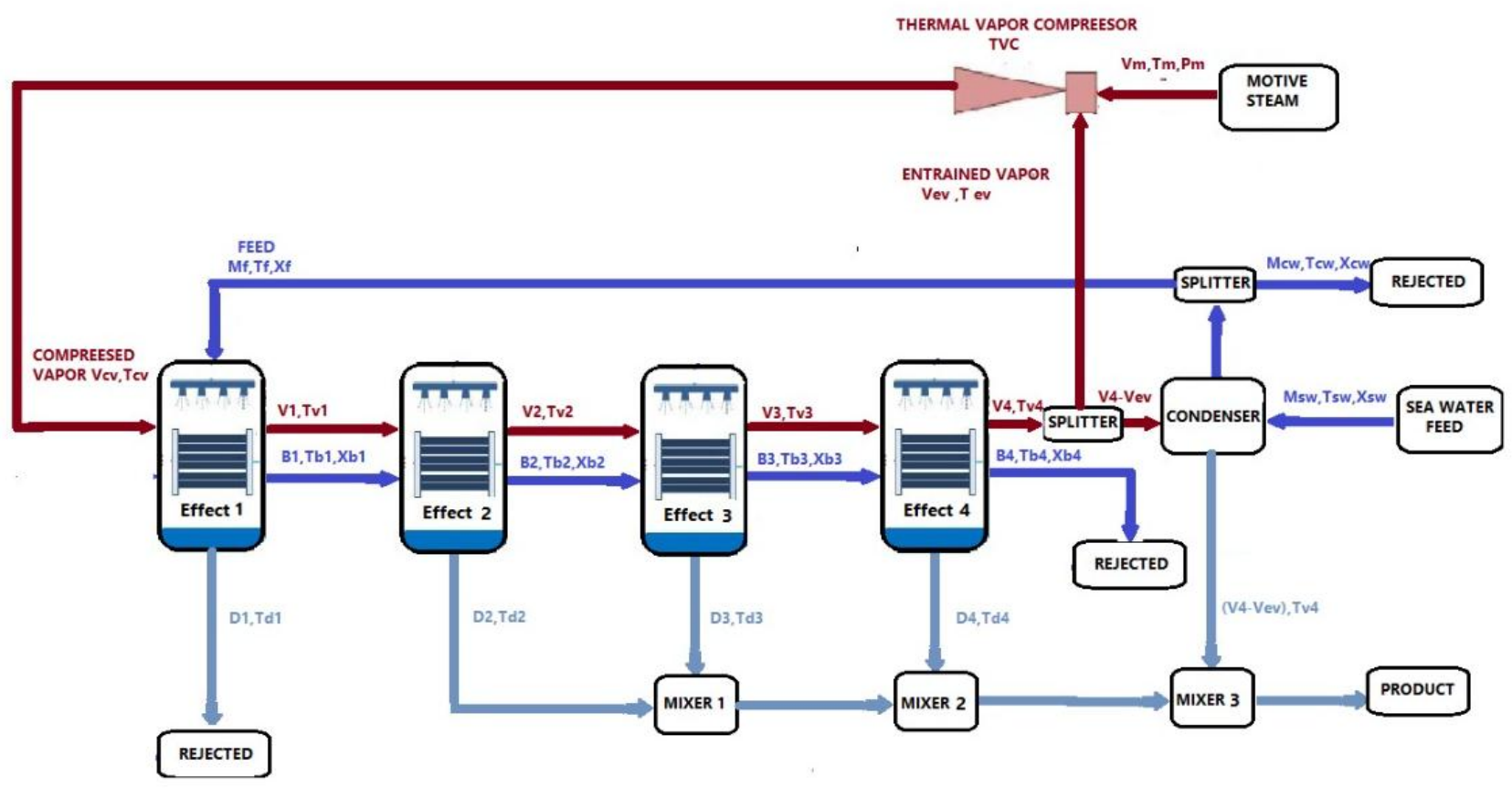

Table 9: Comparison of the output results obtained between our program and data in [16],[17] in case 5

\begin{tabular}{|c|c|c|c|}
\hline Variables & $\begin{array}{c}\text { Developed } \\
\text { program }\end{array}$ & $\begin{array}{c}\text { Khalid et al. } \\
{[22]}\end{array}$ & $\begin{array}{c}\text { Eldesoukey and } \\
\text { Ettouney [18] }\end{array}$ \\
\hline The specific flow rate of cooling water SMcw & 6.816 & 6.788 & 6.819 \\
\hline Total Specific heat transfer Area $\mathrm{SA}\left(\mathrm{m}^{2} /(\mathrm{kg} / \mathrm{s})\right)$ & 346.94 & 346.3 & 345.76 \\
\hline Specific heat transfer condenser area $\mathrm{SA}_{\mathrm{c}}\left(\mathrm{m}^{2} /(\mathrm{kg} / \mathrm{s})\right)$ & 32.786 & 32.92 & 32.79 \\
\hline Performance ratio $\mathrm{PR}$ & 5.262 & 5.275 & 5.260 \\
\hline The Entrainment Ratio $\mathrm{Ra}$ & 2.200 & 2.199 & 2.228 \\
\hline Compression Ratio CR & 3.007 & 3.006 & 3.144 \\
\hline
\end{tabular}


III.VI Case 6: MEE-P/TVC " SIDEM" unit (Maha BenHamad et.al)[20]

A commercial unit installed in the Tunisian Chemical Group (GCT) factory is used to validate the developed program. The input data for the case is shown in Table 10, the output results of the developed program are compared with Maha
BenHamad et.al [20] results. It was found that acceptable results were obtained as shown in Table 11 and 12 for threeevaporator parallel feed plant with thermal vapor compressor, Fig. 6. The heat transfer areas of the three effects are $131.647,118.158$ and $147.964 \mathrm{~m}^{2}$. The heat transfer area of the condenser is $56.555 \mathrm{~m}^{2}$.

THERMAL VAPOR COMPREESOR

$$
\text { TVC }
$$

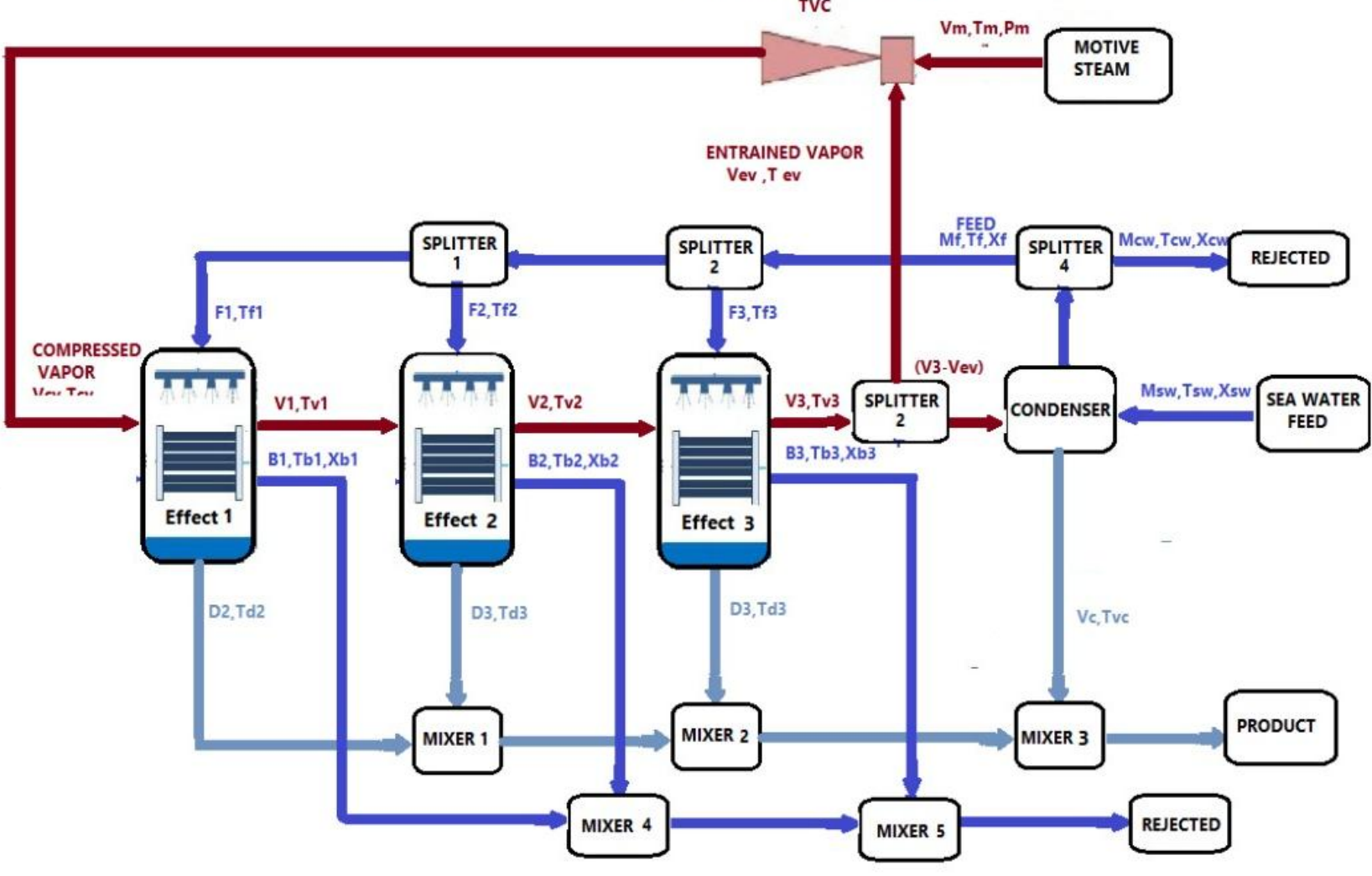

Fig. 6: MEE-P/TVC plant

Table 10: Input data for case 6 [20]

\begin{tabular}{|c|c|c|c|}
\hline \multirow{2}{*}{ Parameter } & Value & Unit \\
\hline \multirow{3}{*}{ Seawater } & Mass flow rate & 220 & ton/ $\mathrm{h}$ \\
\cline { 2 - 4 } & Temperature & 28 & ${ }^{\circ} \mathrm{C}$ \\
\cline { 2 - 4 } & Pressure & 3 & $\mathrm{Bar}$ \\
\cline { 2 - 4 } & Salinity & 39,000 & $\mathrm{Ppm}$ \\
\hline \multirow{3}{*}{ Motive Steam } & Mass flow rate & 3 & ton/ $\mathrm{h}$ \\
\cline { 2 - 4 } & Temperature & 170 & ${ }^{\circ} \mathrm{C}$ \\
\cline { 2 - 4 } & Pressure & 5 & $\mathrm{Bar}$ \\
\hline \multirow{3}{*}{ Condenser } & Pressure drop tube & 0.3 & $\mathrm{Bar}$ \\
\cline { 2 - 4 } & Pressure drop shell & 0 & $\mathrm{Bar}$ \\
\cline { 2 - 4 } & Temperature drop & 6 & ${ }^{\circ} \mathrm{C}$ \\
\hline \multirow{3}{*}{ Ejector } & Pressure output & 0.25 & $\mathrm{Bar}$ \\
\hline \multirow{3}{*}{ Effects } & Temperature E1 & 60 & ${ }^{\circ} \mathrm{C}$ \\
\hline & Temperature E2 & 50 & ${ }^{\circ} \mathrm{C}$ \\
\cline { 2 - 4 } & Temperature E3 & 40 & ${ }^{\circ} \mathrm{C}$ \\
\hline \multicolumn{2}{|c|}{ Cooling seawater Mass flow rate } & 160 & ton $/ \mathrm{h}$ \\
\hline \multicolumn{2}{|c|}{ Feed to effects Mass flow rate } & 20 & ton/ $\mathrm{h}$ \\
\hline
\end{tabular}


International Journal of Engineering Research and Technology. ISSN 0974-3154, Volume 13, Number 10 (2020), pp. 3029-3042

(C) International Research Publication House. https://dx.doi.org/10.37624/IJERT/13.10.2020.3029-3042

Table 11: Comparison of the output results obtained for effect temperature, ${ }^{\circ} \mathrm{C}$, brine , andvapor flow rate, $\mathrm{kg} / \mathrm{s}$ using our program in case 6

\begin{tabular}{|c|c|c|c|c|c|c|c|c|c|}
\hline \multirow{2}{*}{ Variables } & \multicolumn{3}{|c|}{ Effect 1 } & \multicolumn{3}{c|}{ Effect 2 } & \multicolumn{3}{c|}{ Effect 3 } \\
\cline { 2 - 11 } & $\begin{array}{c}\text { Develope } \\
\text { d } \\
\text { program }\end{array}$ & $\begin{array}{c}\text { Maha } \\
\text { BenHamad } \\
\text { et.al[20] }\end{array}$ & ARE\% & $\begin{array}{c}\text { Develope } \\
\text { d } \\
\text { program }\end{array}$ & $\begin{array}{c}\text { Maha } \\
\text { BenHamad } \\
\text { et.al[20] }\end{array}$ & ARE\% & $\begin{array}{c}\text { Develope } \\
\text { d } \\
\text { program }\end{array}$ & $\begin{array}{c}\text { Maha } \\
\text { BenHamad } \\
\text { et.al[20] }\end{array}$ & $\begin{array}{c}\text { ARE } \\
\%\end{array}$ \\
\hline $\begin{array}{c}\text { Vapor } \\
\text { ton/h) }\end{array}$ & 7.808 & 7.067 & 10.480 & 7.096 & 6.376 & 11.292 & 6.748 & 6.451 & 4.605 \\
\hline $\begin{array}{c}\text { Brine } \\
\text { ton/h) }\end{array}$ & 12.896 & 12.935 & 0.3025 & 12.741 & 13.622 & 6.466 & 12.676 & 13.550 & 6.448 \\
\hline temperature & 59.289 & 59.224 & 0.110 & 49.359 & 49.256 & 0.209 & 39.408 & 39.287 & 0.308 \\
\hline
\end{tabular}

Table 12: Comparison of the output results obtained between our program and data in [20] in case 6

\begin{tabular}{|l|c|c|c|}
\hline \multicolumn{1}{|c|}{ Variables } & $\begin{array}{c}\text { Maha } \\
\text { BenHamad } \\
\text { et.al[20] }\end{array}$ & Actual data & Developed program \\
\hline Entrained vapor flow rate Vev (ton/h) & 4.946 & 4.5 & 5.317 \\
\hline The pressure of entrained vapor Pev (bar) & 0.073 & 0.074 & 0.072 \\
\hline Compression Ratio CR & 3.38 & - & 3.391 \\
\hline The Entrainment Ratio Ra & 2.283 & - & 2.292 \\
\hline Specific enthalpy of compressed vapor Hcv $(\mathrm{kJ} / \mathrm{kg})$ & 2645.6 & - & 2653.6 \\
\hline Specific heat transfer area sA $\left(\mathrm{m}^{2} / \mathrm{kg} / \mathrm{s}\right)$ & 73.911 & - & 76.43 \\
\hline
\end{tabular}

\section{RESULTS AND DISCUSSION}

This study presents an efficient program written using MATLAB 2020 programming language. The developed program is used for design and performance calculations for different configurations of multiple-effect evaporator (MEE) systems under different operating conditions based on graph theory principles. The program is verified through six case studies expressing different configurations. The first three cases show a comparison of the design and the performance computation modes of the developed program for forward, backward and mixed feed configurations respectively. The maximum absolute relative error $(A R E)$, which is the absolute ratio of the difference between the reference and calculated values to the reference value, for the first three cases are $0.6173 \%, 0.7619 \%, 1.7482 \%$ (design results are set as the reference values). This result shows that the design and performance calculations modes give acceptable match.The fourth case shows the comparison of the developed program results with Darwish and Hasan model results [19] for a foureffect parallel feed plant where the maximum $A R E$ is $10.204 \%$.The fifth case shows the comparison of the developed program results with Khalid et al. [22] model results for a four-effect MEE-FF/TVC configuration where the maximum $A R E$ is $0.412 \%$. The sixth case shows the comparison of the program results with Maha BenHamad et.al [20] model results for the three-effect MEE-P/TVC SIDEM plant where the maximum $A R E$ is $11.292 \%$ (published results are set as the reference values for the last three cases). All comparison cases give comparable results. The maximum absolute relative errors in all cases does not exceed $11.292 \%$ which indicates that the program has potential applicability to work with different configuration for Multiple Effect Evaporator (MEE) desalination plants.

\section{CONCLUSION}

A flexible program is introduced which can be used to design and simulate different plant configurations for Multiple Effect Evaporator (MEE) desalination plants under different operating conditions. The program enables the operator to excute different modifications for the existing plant.

The developed program has three calculations modes include design and performance analysis of MEE processes. The developed program constructs a large matrix that is solved for temperatures, flow rates of the brine and vapor for all units. The capability of the MatLab platform in the development process of the present program is implemented in this work. Different cases for different desalination plant configurations are analyzed and studied using the developed program of this work. The studied configurations include forward, backward, parallel and mixed plants. The solution results are verified by comparison with some published articles yielding accurate results. 
International Journal of Engineering Research and Technology. ISSN 0974-3154, Volume 13, Number 10 (2020), pp. 3029-3042

(C) International Research Publication House. https://dx.doi.org/10.37624/IJERT/13.10.2020.3029-3042

\section{APPENDIX}

I. The mathematical model for effect unit

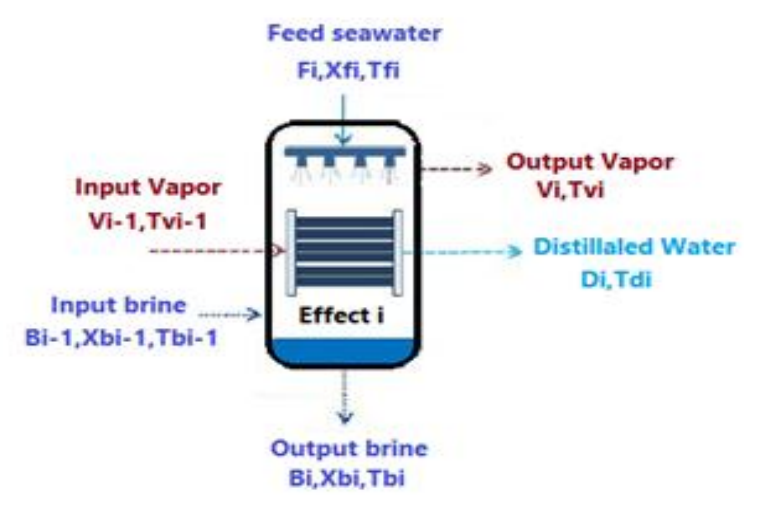

Fig.1. Effect unit

$\Delta T=T_{s}-T_{n}$

(1)

For design mode for same area, it requires to calculate new temperature drop in each effect for each iteration using the following equation:

$\Delta T_{i}=\frac{T_{B 1}-T_{B n}}{n-1} \quad \forall i=1 \ldots n$

$Q_{e 1}=V_{s} \lambda_{s}=A_{e 1} U_{e 1}\left(T_{s}-T_{B 1}\right) \quad i=1$

$V_{i-1}-D_{i}=0$

$Q_{e i}=V_{i-1} \lambda_{v i-1}=V_{i} \lambda_{v i}+F_{i} C p_{i}\left(T_{B i}-T_{f i}\right)$

$Q_{e 1}=V_{s} \lambda_{s}=A_{e 1} U_{e 1}\left(T_{s}-T_{B 1}\right) \quad i=1$

$Q_{e i}=V_{i-1} \lambda_{v i-1}$ $\forall i=2 \ldots n$

$Q_{e i}=A_{e i} U_{e i}\left(\Delta T_{i}-B P E_{i}\right)^{\prime}$

$V^{f b}{ }_{i} \lambda^{f b}{ }_{i}-B_{i-1} C p_{i} \Delta T_{i}=0 \quad i=1$

$T_{v i-1}-T_{d i}=0$

$T_{B i}-T_{i}^{f b}=0$

$$
T_{B i}-T_{v i}=B P E_{i}
$$

If the areas are different, repeat from equation (3) to (10) until the difference between the pervious output and the recent output less than tolerance. Otherwise, repeat from equation (3) to $(11)$

$\Delta T_{i}^{n e w}=\frac{\Delta T_{i} A_{i}}{A_{m}}$

\section{The mathematical model for the condenser unit}

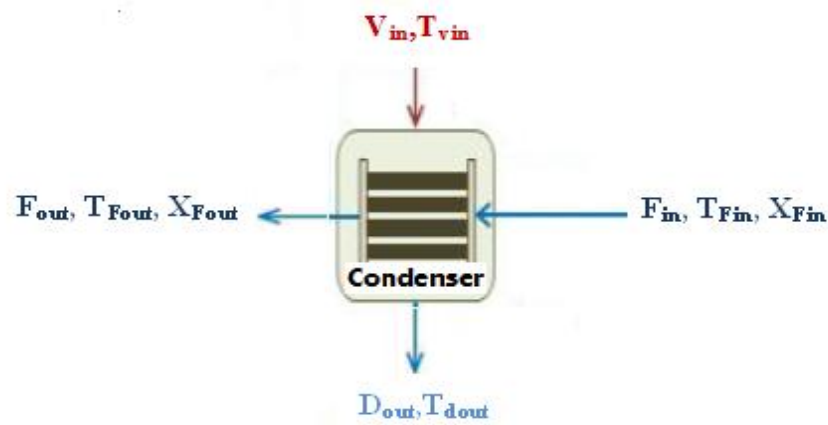

Fig.2. Condenser unit

$$
F_{\text {in }}-F_{\text {out }}=0
$$

$V_{\text {in }}-D_{\text {out }}=0$

$Q_{c}=V_{\text {in }} \lambda_{\text {vin }}-F_{\text {in }} C p_{c}\left(T_{\text {Fout }}-T_{\text {Fin }}\right)=0$

$Q_{c}=V_{i n} \lambda_{v i n}=A_{c} U_{c} L_{M T D}$

$$
\operatorname{LMTD}_{c}=\frac{T_{\text {Fout }}-T_{\text {Fin }}}{\ln \left(\frac{T_{\text {vin }}-T_{\text {Fin }}}{T_{\text {vin }}-T_{\text {Fout }}}\right)}
$$

\section{The mathematical model for steam ejector unit}

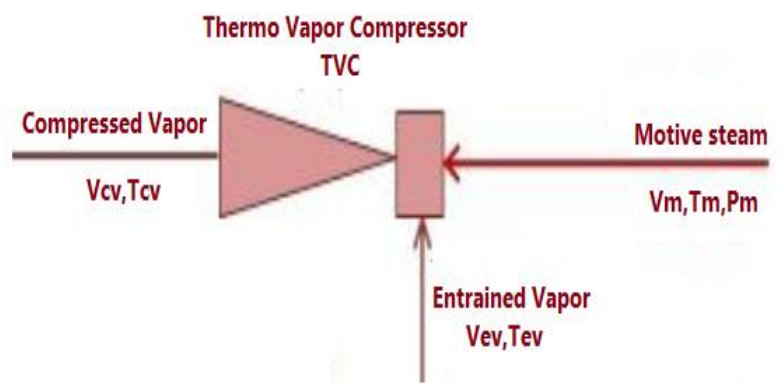

Fig.3. Steam ejector unit

$$
\begin{aligned}
& V_{c v}=V_{m}+V_{e v} \\
& P C F=3 \times 10^{-7} P_{m}{ }^{2}-0.0009 P_{m}+1.0161 \\
& T C F=2 \times 10^{-8} T_{e v}{ }^{2}-0.0006 T_{e v}+1.0047
\end{aligned}
$$


International Journal of Engineering Research and Technology. ISSN 0974-3154, Volume 13, Number 10 (2020), pp. 3029-3042 (C) International Research Publication House. https://dx.doi.org/10.37624/IJERT/13.10.2020.3029-3042

$R a=0.296 \frac{P_{s}^{1.19}}{P_{e v}^{1.04}}\left(\frac{P_{m}}{P_{e v}}\right)^{0.015}\left(\frac{P C F}{T C F}\right)$

$C r=\frac{M_{d}}{M_{f}}$

Where $P_{m}$ is in $\mathrm{kPa}$ and $T_{e v}$ is in ${ }^{\circ} \mathrm{C}$. The previous equations are valid only for ejector operating with steam as the motive fluid and the entrained gas is water vapor. These equations are valid in the following ranges:

$R a<4,500>T_{e v}>10^{\circ} \mathrm{C}, 3500>P_{m}>100 \mathrm{kPa}$, and $\frac{P_{s}}{P_{e v}}>$

1.81

After that the performance parameters are calculated as follows:

$$
P R=\frac{M_{d}}{M_{m}}
$$

\section{Thermodynamics and heat transfer coefficient correlation}

IV. I Seawater specific heat at constant pressure [7]

The seawater specific heat at constant pressure is given by the following Correlation

$C p=\left(A+B T+C T^{2}+D T^{3}\right) * 10^{-3}$

The variables A, B, C and D are evaluated as a function of the water salinity as follows:

$$
\begin{aligned}
& A=4206.8-6.6197 s+1.2288 * 10^{-2} s^{2} \\
& B=-1.1262+5.4178 * 10^{-2} s-2.2719 * 10^{-4} s^{2} \\
& C=1.2026 * 10^{-2}-5.3566 * 10^{-4} s+1.8906 * 10^{-6} s^{2} \\
& D=6.8777 * 10^{-7}+1.517 * 10^{-6} s-4.4268 * 10^{-9} s^{2}
\end{aligned}
$$

Where $C p$ in $\mathrm{kJ} / \mathrm{kg}{ }^{\mathrm{O}} \mathrm{C}$, $\mathrm{T}$ in ${ }^{\circ} \mathrm{C}$, and $s$ is the water salinity in $\mathrm{gm} / \mathrm{kg}$. The above correlation is valid over salinity and temperature ranges of $20000<X<160000$ ppm and $20<\_T<$ $180^{\circ} \mathrm{C}$, respectively.

\section{II Latent heat of water evaporation[11]}

$$
\begin{aligned}
\lambda= & 597.49-5.6624 * 10^{-1} T+1.5082 * 10^{-4} T^{2} \\
& -3.2764 * 10^{-6} T^{3}
\end{aligned}
$$

$\lambda$ : Latent heat of vaporization in, $\mathrm{kcal} / \mathrm{kg}$

$T$ :Temperature in ${ }^{\mathrm{O}} \mathrm{C}$

\section{III Saturated pressure [24]}

$$
\begin{aligned}
\ln (P)=a+ & b \ln \left(T_{r}\right)+c\left[\ln \left(T_{r}\right)\right]^{2}+d\left[\ln \left(T_{r}\right)\right]^{3} \\
& +e T_{r}{ }^{5}
\end{aligned}
$$

\begin{tabular}{|c|c|c|c|c|}
\hline $\mathrm{A}$ & B & $\mathrm{C}$ & $\mathrm{D}$ & $\mathrm{E}$ \\
\hline 9.56756 & 5.39806 & -6.16183 & 1.49572 & 0.43300 \\
\hline
\end{tabular}

The correlation for the water vapor saturation pressure is given by

$T_{r}$ is the reduced temperature, which is defined as T/Tcr. $T_{c r}$ is the critical temperature for steam it is $647.096 \mathrm{~K}$. Values of a to are given in Table 1.

Table .1

\section{IV Saturated temperature [24]}

The correlation for the water vapor saturation pressure is given by

$$
\ln (T)=\left[a+b P_{r}+c P_{r}^{2}+d P_{r}^{3}+e P_{r}^{5}\right]^{0.4}
$$

$P_{r}$ is the reduced pressure, which is defined as $P / P c r . \quad P_{c r}$ is the critical pressure for steam it is $22.064 M P a$. Values of $a$ to $e$ are given in Table 2 .

Table A.2

\begin{tabular}{ccccc}
\hline A & B & C & D & E \\
\hline $9.37817 \mathrm{E}-03$ & $4.98951 \mathrm{E}-04$ & $1.11049 \mathrm{E}-05$ & $3.34995 \mathrm{E}-07$ & $3.44102 \mathrm{E}-08$ \\
\hline
\end{tabular}

\section{V Boiling Point Elevation (BPE) [7]}

The correlation for the boiling point elevation of seawater is

$B P E=A X+B X^{2}+C X^{3}$

$$
\begin{aligned}
& A=8.325 * 10^{-2}+1.883 * 10^{-4} T+4.02 * 10^{-6} T^{2} \\
& B=-7.625 * 10^{-4}+9.02 * 10^{-5} T-5.2 * 10^{-7} T^{2} \\
& C=1.522 * 10^{-4}-3 * 10^{-6} T-3 * 10^{-8} T^{2}
\end{aligned}
$$

Where $T$ is the temperature in ${ }^{\circ} \mathrm{C}$ and $X$ is the salt weight percentage. The above equation is valid over the following ranges: $1<X<16 \%, 10<T<180{ }^{\circ} \mathrm{C}$.

\section{VI Evaporator overall heat transfer coefficient [7]}

The overall heat transfer coefficient in the evaporator is calculated using the following equation.

$$
\begin{aligned}
U_{e}= & 1.9695+1.2057 * 10^{-2} T_{B}-8.5989 * 10^{-5} T_{B}{ }^{2} \\
& +2.25651 * 10^{-7} T_{B}{ }^{3}
\end{aligned}
$$

The units of $\left(U_{e}\right)$ and $\left(T_{B}\right)$ are $\mathrm{kW} / \mathrm{m}^{2}{ }^{\circ} \mathrm{C}$ and ${ }^{\circ} \mathrm{C}$, respectively.

\section{VII Condenser overall heat transfer coefficient [7]}

The overall heat transfer coefficient in the condenser is calculated using the following equation.

$$
\begin{aligned}
U_{c}= & 1.7194+3.2063 * 10^{-3} T_{v}+1.5971 * 10^{-5} T_{v}{ }^{2} \\
& -1.9918 * 10^{-7} T_{v}{ }^{3}
\end{aligned}
$$

The units of $\left(U_{c}\right)$ and $\left(T_{v}\right)$ are $\mathrm{kW} / \mathrm{m}^{2}{ }^{\mathrm{O}} \mathrm{C}$ and ${ }^{\mathrm{O}} \mathrm{C}$, respectively.

\section{Nomenclature}

$\begin{array}{ll}\Delta T & : \text { Total temperature, }{ }^{\circ} \mathrm{C} \\ \Delta T_{i} & : \text { Temperature drop in each effect, }{ }^{\circ} \mathrm{C} \\ T_{s} & : \text { Inlet steam/vapor for the first effect, }{ }^{\circ} \mathrm{C} \\ T_{n} & : \text { Temperature from last effect, }{ }^{\circ} \mathrm{C} \\ B & : \text { Brine flow rate, } \mathrm{Kg} / \mathrm{hr} \\ V & : \text { Vapor flow rate, } \mathrm{Kg} / \mathrm{hr} \\ F & : \text { Feed flow rate, } \mathrm{Kg} / \mathrm{hr} \\ Q_{e i} & : \text { Heat flows in effect } \mathrm{i}, \mathrm{Kj} / \mathrm{hr} \\ A_{e i} & : \text { Heat transfer area of effect } \mathrm{i}, \mathrm{m}^{2} \\ M_{f} & : \text { Feed flow rate to first effect, } \mathrm{Kg} / \mathrm{hr} \\ M_{s} & : \text { Total product flow rate to first effect, } \mathrm{Kg} / \mathrm{hr} \\ Q_{c} & : \text { Thermal load of the condenser, } \mathrm{Kj} / \mathrm{hr} \\ A_{c} & : \text { Heat transfer area of condenser, } \mathrm{m}^{2} \\ L_{M T D} & : \text { Logarithmic mean temperature difference, }{ }^{\circ} \mathrm{C}\end{array}$




$\begin{array}{ll}X & : \text { Salinity, ppm } \\ U & : \text { Overall heat transfer coefficient, } \mathrm{KJ} / \mathrm{hr} . \mathrm{m}^{2} .{ }^{\circ} \mathrm{C} \\ C p & : \text { Specific heat at a constant preesure, } \mathrm{KJ} / \mathrm{Kg} .{ }^{\circ} \mathrm{C} \\ P R & : \text { Performance ratio } \\ B P E & : \text { Boiling Point Elevation, }{ }^{\circ} \mathrm{C} \\ A R E & : \text { Absolute relative error, } \% \\ \lambda & : \text { Latent heat, } \mathrm{KJ} / \mathrm{Kg}\end{array}$

\section{REFERENCES}

[1] IDA, IDA desalination yearbook 2016-2017, Oxford: Media Analytics Ltd, 2016.

[2] Kaldellis, J. K., K. A. Kavadias, and E. Kondili. "Renewable energy desalination plants for the Greek islands- technical and economic considerations." Desalination 170.2 (2004): 187-203.

[3] Nafey, A. S., H. E. S. Fath, and A. A. Mabrouk. "Thermo-economic investigation of multi effect evaporation (MEE) and hybrid multi effect evaporation-multi stage flash (MEE-MSF) systems." Desalination 201.1-3 (2006): 241-254.

[4] Al-Mutaz. "Features of multi-effect evaporation desalination plants." Desalin.Water Treat. 54 (2014) 3227-3235.

[5] M. Salimi, M. Amidpour." Modeling, performance, parametric study and economic assessment of reciprocating internal combustion engine integrated with multi-effect desalination unit."Energy Convers. Manage. 138 (2017) 299-311.

[6] Nafey, A. S., Fath, H. E. S., Mabrouk, A. A., and Elzzeky, M. A. "A new visual package for performance of thermal desalination processes: development and verification." Eighth International Water Technology Conference, IWTC8. 2004.

[7] Nafey, A. S., "Design and Performance of Seawater Thermal Desalination Plants." Ph.D. Dissertation, University of Leeds, United Kingdom, 1988.

[8] Durmus Kaya and H. Ibrahim Sarac "Mathematical Modeling of Multiple-Effect Evaporators and Energy Economy."Energy 2007;32 (8):1536-1542

[9] Hamed, O. A., and S. Aly. "Simulation and design of MSF desalination processes." Desalination 80.1 (1991): $1-14$.

[10] Itahara, Seiji, and L. I. Stiel. "Optimal design of multiple-effect evaporators by dynamic programming." Industrial \& Engineering Chemistry Process Design and Development 5.3 (1966): 309-315.

[11] Perz, E. "A computer method for thermal power cycle calculation." (1991): 184-189.

[12] Bourouis, M., Pibouleau, L., Floquet, P., Domenech, S., and Al-Gobaisi, D. M. "Simulation and data validation in multistage flash desalination plants." Desalination 115.1 (1998): 1-14.

[13] Sharaf, M. A. (2011)." Design and performance of solar desalination systems." Ph. D thesis, Suez Canal University.
[14] van der Lee, Patrick EA, Tamás Terlaky, and Theo Woudstra. "A new approach to optimizing energy systems." Computer methods in applied mechanics and engineering 190.40-41 (2001): 5297-5310.

[15] Uche, J., Serra, L., Herrero, L. A., Valero, A., Turégano, J., and Torres, C. "Software for the analysis of water and energy systems." Desalination 156.1-3 (2003): 367-378.

[16] Nafey, A. S., M. A. Sharaf, and Lourdes GarcíaRodríguez. "A new visual library for design and simulation of solar desalination systems (SDS)." Desalination 259.1-3 (2010): 197-207.

[17] H.T. El-Dessouky, I. Alatiqi, S. Bingulac, H.M. Ettouney. "Steady-State Analysis of the Multiple Effect Evaporation Desalination Process." Chem. Eng. Process. 21 (1998) 437-451

[18] El-Dessouky, H. T. and Ettouney, H. M. "Fundamentals of Sea Water Desalination." book first edition 2002.

[19] M. A. Darwish and Hassan K. Abdulrahim "Feed Water Arrangements in a Multi-Effect Desalting System." Desalination 228 (2008) 30-54

[20] Maha, BenHamad, Snoussi Ali, and Ben Brahim Ammar. "Modeling and performance of multi-effect desalination plant (SIDEM unit)." 2017 International Conference on Green Energy Conversion Systems (GECS). IEEE, 2017.

[21] Samanta, P. "Introduction to Graph Theory." 10.13140/RG.2.2.25721.88166, 2011.

[22] K. A. Khalid, M. A. Antar, A. Khalifa, and O. A. Hamed. "Allocation of Thermal Vapor Compressor in Multi-Effect Desalination Systems With Different Feed Configurations." Desalination 426 (2018) 164-173

[23] A. A. Mabrouk, "A Visual Flowsheeting Program for Thermoeconomic Analysis of Desalination Processes." Ph.D. Dissertation, Suez Canal University, Egypt, 2006.

[24] Alatiqi, I., El-Dessouky, H. T. and Ettouney, H. M. "Technology transfer in desalination processes.", J. Tech. Trans., 1999, in press.

[25] A. S. Nafey, H. E. S. Fath and A. A. Mabrouk, "A New Visual Package for Design and Performance of Desalination Processes." Desalination, 194 (2006) 81296.

[26] A. S. Nafey, H. E. S. Fath and A. A. Mabrouk, "Exergy and Thermoeconomic Evaluation of MSF Process using a New Visual Package." Desalination, 201 (2006) 224240.

[27] A. S. Nafey, H. E. S. Fath and A. A. Mabrouk, "Thermoeconomic Investigation of Multi-Effect Evaporation (MEE) and Hybrid Multi-Effect Evaporation - Multi-Stage Flash (MEE-MSF) Systems." Desalination, 201 (2006) 241-254.

[28] Lambart, R. N., Joye, D. D., and Koko, F. W., "Design Calculations for Multiple-Effect Evaporators. 1. Linear Method. " Ind. Eng. Chem. Res. 1987, 26, 100 - 104. 
International Journal of Engineering Research and Technology. ISSN 0974-3154, Volume 13, Number 10 (2020), pp. 3029-3042

(C) International Research Publication House. https://dx.doi.org/10.37624/IJERT/13.10.2020.3029-3042

[29] Lambart, R. N., Joye, D. D., and Koko, F. W., "Design Calculations for Multiple-Effect Evaporators. 2. Comparison of Linear and Nonlinear Methods." Ind. Eng. Chem. Res. 1987, 26, $100-104$.

[30] Jancew-Cudier, Alina, and Claudio Olivera-Fuentes. "A simplified and generalized method to size multipleeffect evaporator systems with any feed scheme." energy 1 (2005): 1.

[31] Affandi, M., Mamata, N., Kanafiaha, S. N. A. M., and Syahirah, N. "Simplified equations for saturated steam properties for simulation purpose." Procedia Engineering 53 (2013): 722-726. 